\title{
The Mode of Action of Silver and Silver Halides Nanoparticles against Saccharomyces cerevisiae Cells
}

\author{
A. A. Kudrinskiy, ${ }^{1,2}$ A. Yu. Ivanov, ${ }^{3}$ E. V. Kulakovskaya, ${ }^{4}$ A. I. Klimov, ${ }^{1}$ P. M. Zherebin, ${ }^{1}$ \\ D. V. Khodarev, ${ }^{5}$ Anh-Tuan Le, ${ }^{6}$ Le Thi Tam, ${ }^{6}$ G. V. Lisichkin, ${ }^{1}$ and Yu. A. Krutyakov ${ }^{1,2}$ \\ ${ }^{1}$ Department of Chemistry, M.V. Lomonosov Moscow State University, Leninskie Gory, building 1-3, Moscow 119991, Russia \\ ${ }^{2}$ National Research Centre "Kurchatov Institute", Akademika Kurchatova pl. 1, Moscow 1 123182, Russia \\ ${ }^{3}$ Institute of Cell Biophysics RAS, Pushchino 142290, Russia \\ ${ }^{4}$ Skryabin Institute of Biochemistry and Physiology of Microorganisms, Prospect Nauki, Pushchino 142290, Russia \\ ${ }^{5}$ Vologda State Pedagogical University, S. Orlov Street 6, Vologda 160035, Russia \\ ${ }^{6}$ Department of Nanoscience and Nanotechnology, Advanced Institute for Science and Technology, \\ Hanoi University of Science and Technology, Dai Co Viet Street, Hai Ba Trung, Hanoi 10000, Vietnam \\ Correspondence should be addressed to Yu. A. Krutyakov; yurii@petrol.chem.msu.ru
}

Received 25 September 2013; Revised 13 November 2013; Accepted 13 November 2013; Published 13 February 2014

Academic Editor: Raphael Schneider

Copyright (C) 2014 A. A. Kudrinskiy et al. This is an open access article distributed under the Creative Commons Attribution License, which permits unrestricted use, distribution, and reproduction in any medium, provided the original work is properly cited.

\begin{abstract}
Silver and silver halides nanoparticles (NPs) ( $\mathrm{Ag}, \mathrm{AgCl}, \mathrm{AgBr}$, and $\mathrm{AgI}$ ) capped with two different stabilizers (sodium citrate and nonionic surfactant Tween 80) were obtained via sodium borohydride reduction of silver nitrate in an aqueous solution. The effect of the biocidal action of as-prepared synthesized materials against yeast cells Saccharomyces cerevisiae was compared to the effect produced by silver nitrate and studied through the measurement of cell loss and kinetics of $\mathrm{K}^{+}$efflux from the cells depending on concentration of silver. The results clearly indicate that the silver ions either remained in the dispersion of silver NPs and silver halides NPs after their synthesis or were generated afterwards by dissolving silver and silver halides particles playing a major part in the cytotoxic activity of NPs against yeast cells. It was also supposed that this activity most likely does not relate to the damage of cell membrane.
\end{abstract}

\section{Introduction}

Since the beginning of the antibiotic era in the early 1930 s and the introduction of sulphonamides and penicillins the application of silver-based compounds in medical practice was of rare occurrence and the use of silver salts in the treatment of patients strictly diminished around the World War II [1]. However the interest in silver has never entirely disappeared and nowadays it reappeared again with the development of nanosilver containing materials and composites mainly due to the rediscovery of high antibacterial activity of colloidal silver particles. At the moment silver in the form of NPs has the highest degree of commercialization among all nanomaterials [2] and became a promising alternative to traditionally used antimicrobial agents in the treatment of delayed wounds [3], burns [4], ulcers, bladder inflammation [5], and other diseases.

Unfortunately, uncontrolled production and thoughtless internal use of silver colloids in the treatment of diseases like influenza, hepatitis, pneumonia, bronchitis, and even HIV-infection in the 1990s forced USA Food and Drug Administration to bring in a ban on "claiming any therapeutic or preventive value for the product, noting that colloidal silver was being marketed for numerous diseases without evidence of safety or effectiveness" in August 1999. As a result, colloidal silver is now seen only as a dietary supplement in the US and is no longer listed in the British National Formulary under products for wound management; also, according to Australian Therapeutic Goods Administration "there are no legitimate medical uses for colloidal silver and no evidence 
to support its marketing claims." Obviously these restrictions are related to possible side effects in humans treated with nanosilver containing medications [6]. Keeping in mind that there is no intelligible point in internal use of nanosilver it should be noted that in order to be toxic externally silver needs to be absorbed into the body in sufficient amounts $[7,8]$. The most common change seen in the skin in response to percutaneous silver absorption is argyria-blue or bluishgrey skin discoloration [9]. At the same time it is well known that argyria is not a serious disease and has only negative cosmetic effects.

In our opinion the aforementioned situation was not only caused by uncontrolled silver internal uses but also by the lack of clear scientific information about colloidal silver action on living cells. Furthermore, there is insufficient number of works $[10,11]$ aiming at the systematical study of the silver NPs action against living cells-neither bacterial nor mammalian. Mechanisms of antibacterial action of silver are poorly researched.

This paper is another step in the process of understanding of the mode of the silver NP's action on living cells.

\section{Experimental Part}

2.1. Chemicals. Polyoxyethylene(20)sorbitan monooleate (Tween 80) was purchased from Acros Organics and used without further purification and silver nitrate (99.9+\%, Sigma-Aldrich), sodium citrate dihydrate (99+\%, SigmaAldrich), sodium borohydride (Lancaster, 98+\%), sodium bromide (99+\%, Sigma-Aldrich), sodium iodide (99,9+\%, Sigma-Aldrich), and sodium chloride (99+\%, SigmaAldrich) were of analytical grade and used without further purification. All aqueous solutions were prepared with doubly distilled water.

2.1.1. Synthesis of Tween 80 Stabilized Silver Halides NPs. The preparation of Tween 80 stabilized colloidal silver halides was performed as follows. Fifty milliliters of $\mathrm{AgNO}_{3}(0.0157 \mathrm{~g}$, $9.2 \times 10^{-5} \mathrm{~mol}$ ) water solution was added dropwise to $50 \mathrm{~mL}$ of Tween 80 aqueous solution with vigorous stirring. The mixture was kept stirred for $15 \mathrm{~min}$. The quantity of Tween 80 was adjusted to $0.05 \%\left(5 \times 10^{-4} \mathrm{~g} \mathrm{~mL}^{-1}\right)$ total concentration in the reaction mixture. Then $100 \mathrm{~mL}$ of sodium halide $(9.2$ $\times 10^{-5} \mathrm{~mol}$ ) water solution was added dropwise with intense stirring.

2.1.2. Synthesis of Citrate Stabilized Silver NPs. The preparation of citrate stabilized Ag-NPs was performed as follows. $50 \mathrm{~mL}$ of $\mathrm{AgNO}_{3}\left(0.0063 \mathrm{~g}, 3.7 \times 10^{-5} \mathrm{~mol}\right)$ aqueous solution was added dropwise to $50 \mathrm{~mL}$ sodium citrate solution with vigorous stirring. Then two $50 \mathrm{~mL}$ solutions with different concentration of $\mathrm{NaBH}_{4}$ were added step by step $(0.0008 \mathrm{~g}$, $2.1 \times 10^{-5} \mathrm{~mol}$ and $0.0015 \mathrm{~g}, 4 \times 10^{-5} \mathrm{~mol}$, resp.). The quantity of sodium citrate was adjusted to reach $3 \times 10^{-4} \mathrm{~mol} \mathrm{~L}^{-1}$ total concentration of citrate in the reaction mixture. Reduction process was carried out at room temperature.
2.1.3. Synthesis of Silver Halide NPs. Different solutions were made before silver halide synthesis:

(a) $17 \mathrm{mg}(0,0001 \mathrm{~mol})$ of $\mathrm{AgNO}_{3}$ was dissolved in $50 \mathrm{~mL}$ of water;

(b) $58.5 \mathrm{mg}(0,0001 \mathrm{~mol})$ of $\mathrm{NaCl}$ was dissolved in $50 \mathrm{~mL}$ of water;

(c) $103 \mathrm{mg}(0,0001 \mathrm{~mol})$ of $\mathrm{NaBr}$ was dissolved in $50 \mathrm{~mL}$ of water;

(d) $150 \mathrm{mg}(0,0001 \mathrm{~mol})$ of $\mathrm{NaI}$ was dissolved in $50 \mathrm{~mL}$ of water;

(e) $20 \mathrm{mg}$ of sodium citrate was dissolved in $100 \mathrm{~mL}$ of water;

(f) $2.3 \mathrm{mg}$ of sodium 3-mercaptopropanesulfonate was dissolved in $100 \mathrm{~mL}$ of water;

(g) $100 \mathrm{mg}$ of polyoxyethylene(80)sorbitan monooleate (Tween 80 ) was dissolved in $100 \mathrm{~mL}$ of water.

The synthesis was carried out in a three-necked flask with a mechanical stirrer and two dropping funnels. $50 \mathrm{~mL}$ of silver nitrate solution and $50 \mathrm{~mL}$ of sodium halide solution were slowly ( $1 \mathrm{~mL}$ per minute) and simultaneously dropped into $100 \mathrm{~mL}$ of stabilizer solution with vigorous stirring. After that the final dispersion was stirred about $60 \mathrm{~min}$ and asprepared solution was held in a dark under argon.

2.2. Measurements. The UV-vis absorbance spectra were recorded using a Shimadzu UV-1800 spectrophotometer (Japan), and $1 \mathrm{~mm}$ path length quartz cuvettes were used for the measurement of visible spectra.

The electronic images and diffractograms were made on Leo 912 AB Omega (Leo Ltd., Germany) transmission electron microscope (TEM) operating at $100 \mathrm{kV}$. The samples for TEM characterization were prepared by placing a drop of a colloidal solution on a formvar-coated copper grid which was dried at room temperature. All size distribution was calculated using Femtoscan Online v. 2.2.91 software (Advanced Technologies Center, Russia).

Zeta potential measurements of the obtained dispersions were carried out on Zetasizer Nano ZS analyzer with integrated $4 \mathrm{~mW}$ He-Ne laser, $\lambda=633 \mathrm{~nm}$ (Malvern Instruments Ltd.). Zeta potential was measured by applying an electric field across the dispersion of silver NPs using the technique of laser Doppler anemometry.

The concentration of silver ions in NPs suspensions was determined by $\mathrm{Ag}^{+}$-ion selected electrode ( $<<$ELIS-131Ag $>>$, Russia) in the thermostatic cell $(3.0 \mathrm{~mL})$ containing $0.01 \mathrm{M}$ citrate buffer $(\mathrm{pH} 6.0)$ at $20^{\circ} \mathrm{C}$ with agitation. The calibration of electrode was conducted by fractional addition of $0.01 \mathrm{M}$ $\mathrm{AgNO}_{3}$ solution. The electrode ESr-10101/4,2 (Russia) was used as a comparative electrode.

2.2.1. Microbiological Tests. Saccharomyces cerevisiae VKM Y1173 cells were cultivated in the shaken flasks with Reader medium [12] with $2 \%$ glucose at $29^{\circ} \mathrm{C}$ until the culture has reached the logarithmic phase of growth [13]. After that yeast cells were washed with distilled water twice, harvested by 
centrifugation at $5000 \mathrm{~g}$ during $15 \mathrm{~min}$, and stored in a dense water suspension $(0.9-1.2) \times 10^{9}$ cells $/ \mathrm{mL}$ throughout the experiment (3-4 hours) at $0^{\circ} \mathrm{C}$.

To determine S. cerevisiae survival rate after silver nitrate and citrate stabilized silver NPs treatment the primary cell suspension was dissolved in distilled water $(1: 100)$. The studied agents (ionic form of silver $\left(\mathrm{Ag}^{+}\right): 0.01 \mathrm{M}$ aqueous solution of $\mathrm{AgNO}_{3}$ in concentrations from 0.75 to $18 \mu \mathrm{M}$ ) were used. Following silver NPs were used: negatively charged citrate stabilized Ag-NPs in different concentrations from 1.8 to $18 \mu \mathrm{M}$ were added to the cell suspension $\left(\sim 3 \cdot 10^{7}\right.$ cells $\left./ \mathrm{mL}\right)$ containing $0.5 \mathrm{~mL} 0.01 \mathrm{M}$ citrate buffer $(\mathrm{pH} 6.0)$ and incubated during $30 \mathrm{~min}$ at $30^{\circ} \mathrm{C}$. The suspension of nontreated cells was used as a control (100\% of survival rate) sample. Different dilutions (from 1:10 to $1: 1000$ ) of yeast cells $(0.1 \mathrm{~mL})$ were inoculated on Petri plates with agar-agar and incubated during $3-5$ days at $24-30^{\circ} \mathrm{C}$ and then the colony quantity was accounted.

For registration of the $\mathrm{K}^{+}$efflux from $S$. cerevisiae cells the ion selected electrodes $(<<$ Orion $>>$, USA) and $(<<$ ELIS$121 \mathrm{~K}>>$, Russia) [13] were used. The measurements were conducted in the thermostatic cell $(3 \mathrm{~mL})$ at $20^{\circ} \mathrm{C}$ with agitation. Cell suspension $(60 \mu \mathrm{M})$ was added to measurement medium with $0.01 \mathrm{M}$ citrate buffer ( $\mathrm{pH} 6.0$ ) to obtain the cell concentration $\sim 3 \times 10^{7}$ cells $/ \mathrm{mL}$. The common level of S. cerevisiae intracellular $\mathrm{K}^{+}$was determined by addition of $20 \mu \mathrm{M} \mathrm{Ag}^{+}$to cell suspension or after heat treatment at $70^{\circ} \mathrm{C}$ during $15 \mathrm{~min}$ in the water bath. The $\mathrm{K}^{+}$levels determined by the both methods were practically equal. Common $\mathrm{K}^{+}$level determined from native yeast cells was taken as $100 \%$ in the experiments aimed at investigating the effects of nanosilver contained agents.

\section{Discussion}

3.1. NPs Characterization. The manner of preparation of citrate-stabilized silver NPs was in the reduction of silver nitrate aqueous solution containing sodium citrate as noncovalent stabilizer by $\mathrm{NaBH}_{4}$ solution. The optimal concentration of citrate anion turned out to be in a good agreement with [14]. The as-prepared silver NPs had an average diameter about $10 \mathrm{~nm}$, were well dispersed and negatively charged, and their zeta potential was $-29.1 \pm 0.5 \mathrm{mV}$ at $\mathrm{pH}=7.8$. Nanosilver dispersion was stable at least 6 month after synthesis and exhibited surface plasmon bands at $401 \mathrm{~nm}$ corresponding to noncovalently stabilized Ag NPs (Figures 1 and 2).

Dispersion of silver halides $(\mathrm{AgCl}, \mathrm{AgBr}$, and $\mathrm{AgI}$ ) obtained by precipitation from aqueous solutions of silver nitrate in the presence of Tween 80 was characterized using UV-Vis spectroscopy (Figure 3 ) and transmission electron microscopy (Figures 4, 5, and 6).

The figure clearly indicates the offset of the region of absorption to longer wavelengths area passing from silver chloride to bromide and then to iodide, which is consistent with the decrease of photolytic stability of halides in this series.

The mechanism of the stabilizing action of Tween 80 , apparently, is typical for solubilizing surfactant. In our

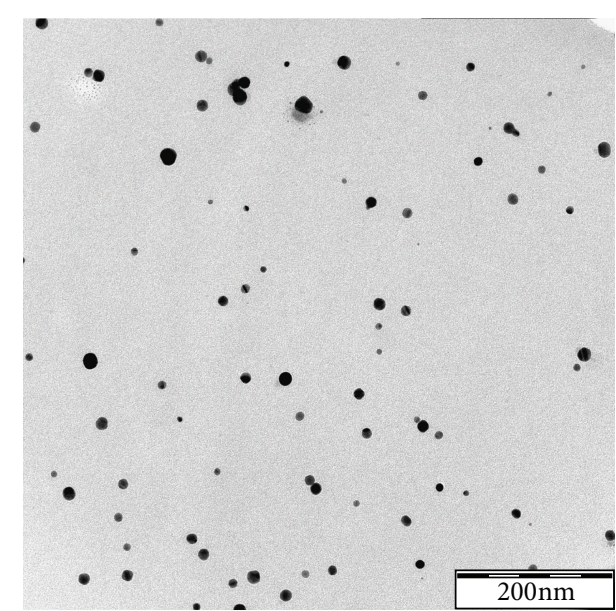

FIgURE 1: TEM image of citrate stabilized silver NPs.

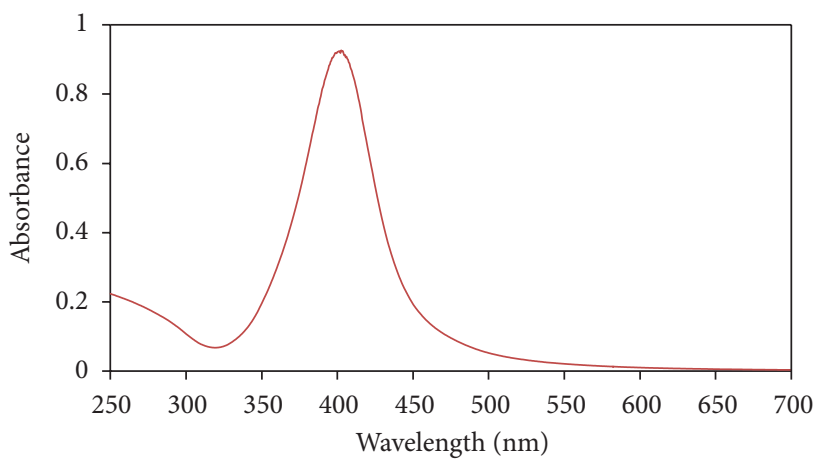

FIGURE 2: UV-visible absorbance spectrum of citrate stabilized silver NPs.

technique Tween 80 was used in concentrations one order greater than its own CMC $(0.8 \mathrm{mM}$ against CMC Tween 80 of $0.08 \mathrm{mM}$ ). Forming around the nanoparticle micelle acts as a wrapper that prevents coagulation but allows silver ions go into solution and back.

3.1.1. Microbiological Activity of Silver Nanoparticles Dispersion. Nowadays three main concepts of antibacterial and antiviral action of nanosilver are commonly accepted and widely discussed. On the one hand, silver NPs themselves can penetrate through cell membrane and interact with organelles, thus leading to disorder of the cell functioning. This mechanism was well proven, for example, with respect to antibacterial and antiviral activity of nanosilver $[15,16]$. On the other hand, silver NPs can easily generate $\mathrm{Ag}^{+}$-ions via oxidation of surface silver atoms by different oxidants dissolved in cytoplasm. So, the silver particles act as a buffer which maintains concentration of $\mathrm{Ag}^{+}$in the surrounding media at the approximately constant level. According to the third concept the bactericidal action of silver NPs is determined by the intermediates formed during the silver oxidation, for example, peroxides and free radicals. 


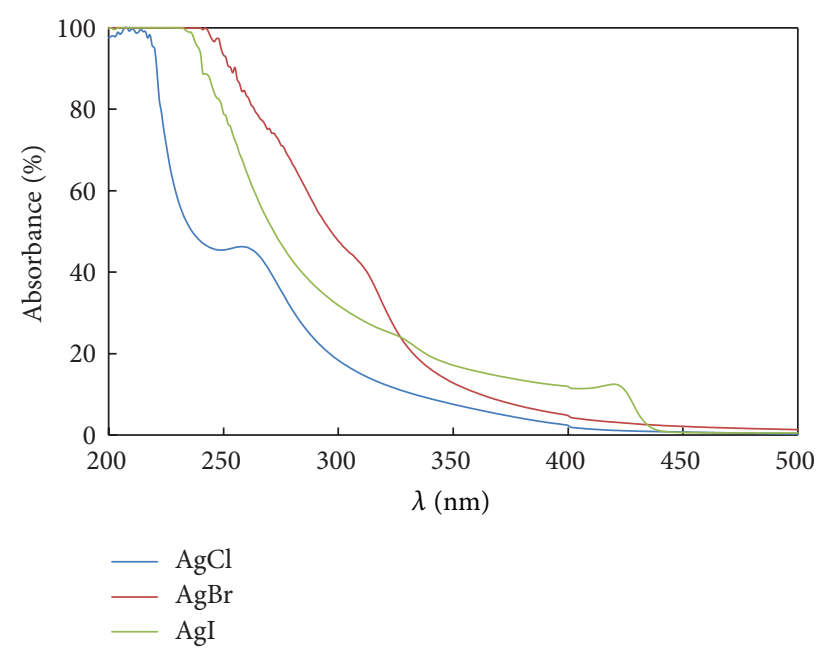

FIGURE 3: UV-visible absorbance spectra of silver halides NPs.
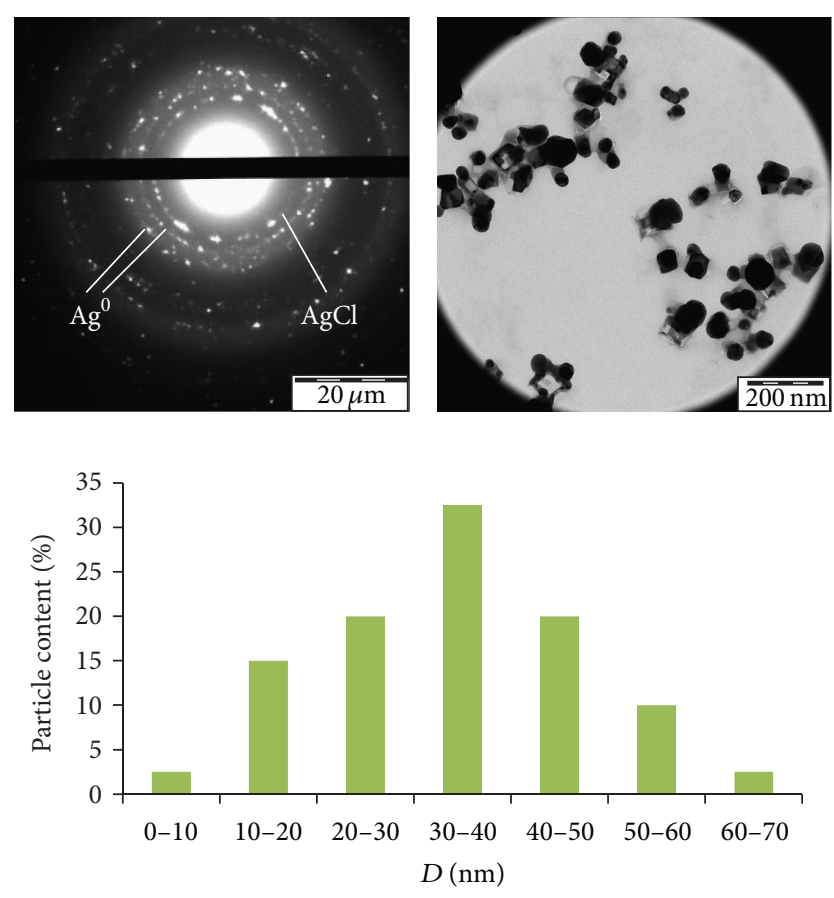

FIGURE 4: Electron micrographs, electron microdiffraction data, and histograms of the size distribution of silver chloride nanoparticles stabilized with Tween 80 .

Actually, the observed antibacterial activity of the nanosilver is a superposition of those three ways. The contribution of each way depends on many factors, which is the reason why the detailed investigation of the mechanism of nanosilver action is necessary for the rational design of silver NPs-based pharmaceutical compositions. The aim of present research was to determine the contribution of silver NPs themselves and silver ions of NPs' origin into the activity of silver and silver halides nanoparticles against Saccharomyces cerevisiae cells.
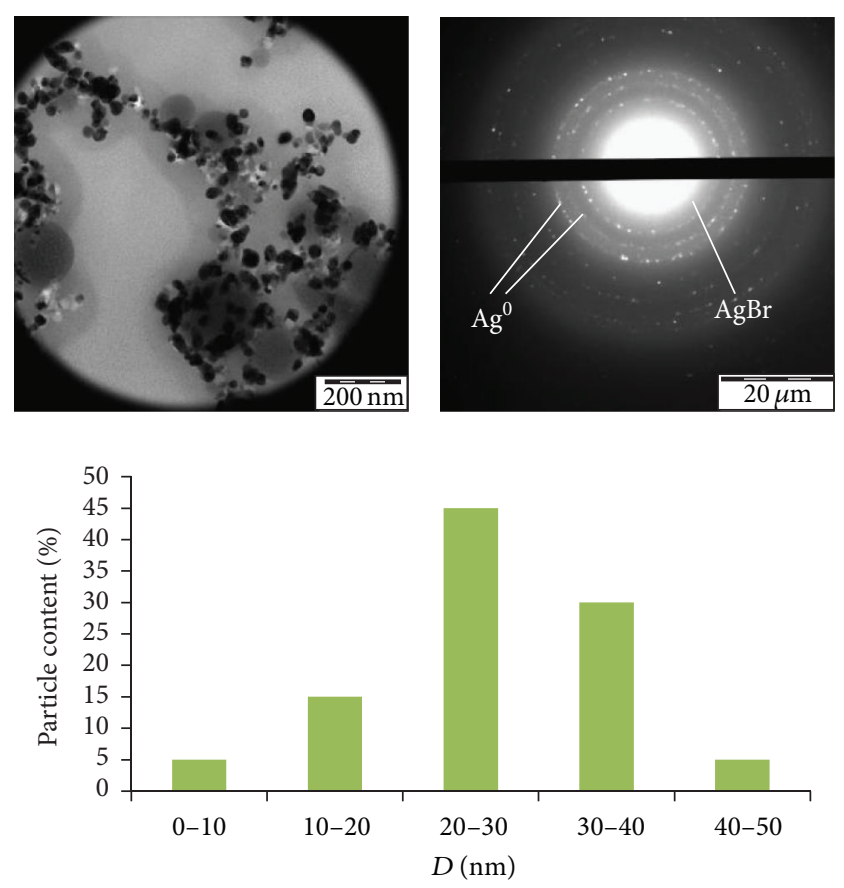

FIGURE 5: Electron micrographs, electron microdiffraction data, and histograms of the size distribution of silver bromide nanoparticles stabilized with Tween 80 .

The cytotoxic activity of silver nanoparticles was characterized by survival rate of yeast cells and by rate of $\mathrm{K}^{+}$efflux from the cells incubated with nanosilver dispersion. The data obtained by those two techniques are in good correlation there between Figures 7 and 8 . The rates of $\mathrm{K}^{+}$efflux and cell loss increase when the concentration of $\mathrm{AgNO}_{3}$ and $\mathrm{Ag} \mathrm{NPs}$ increases. At that, the percentage of cell loss always exceeds the $\mathrm{K}^{+}$efflux at the end of an experiment, thus indicating that some dead cells still contain $\mathrm{K}^{+}$inside. This effect allows to suppose that cytotoxic activity of silver ions and nanoparticles against yeast cells do not relate completely to damage of cell membrane.

The determined rates of $\mathrm{K}^{+}$efflux from the cells incubated with Ag-NPs (Figure 8) were approximately 5 times lower as compared to the cells incubated with $\mathrm{AgNO}_{3}$ of the same concentrations (Figure 9).

Addition of small amounts of $\mathrm{NaBH}_{4}$ into the NPs sol before incubation resulted in dramatic decrease in the $\mathrm{K}^{+}$ efflux (Figure 10). On the contrary, the addition of dilute $\mathrm{H}_{2} \mathrm{O}_{2}$ to the cells incubated with silver NPs led to a significant increase in the rate of $\mathrm{K}^{+}$efflux. It should be noted that $\mathrm{NaBH}_{4}$ and $\mathrm{H}_{2} \mathrm{O}_{2}$ themselves in the studied concentrations did not affect the cells' survival rate. Therefore, the additions of $\mathrm{NaBH}_{4}$ and $\mathrm{H}_{2} \mathrm{O}_{2}$ does not directly affect the yeast cell functioning. Those chemicals alter the rate of $\mathrm{K}^{+}$efflux indirectly by modifying the concentration of $\mathrm{Ag}^{+}$-ions due to reduction of $\mathrm{Ag}^{+}$by $\mathrm{NaBH}_{4}$ or at least partial oxidation of silver particles by $\mathrm{H}_{2} \mathrm{O}_{2}$. Since the reduction of $\mathrm{Ag}^{+}$led to total disappearance of the nanosilver activity it can be concluded that the activity of the studied silver NPs happens only due to the activity of silver ions. On the basis of this 

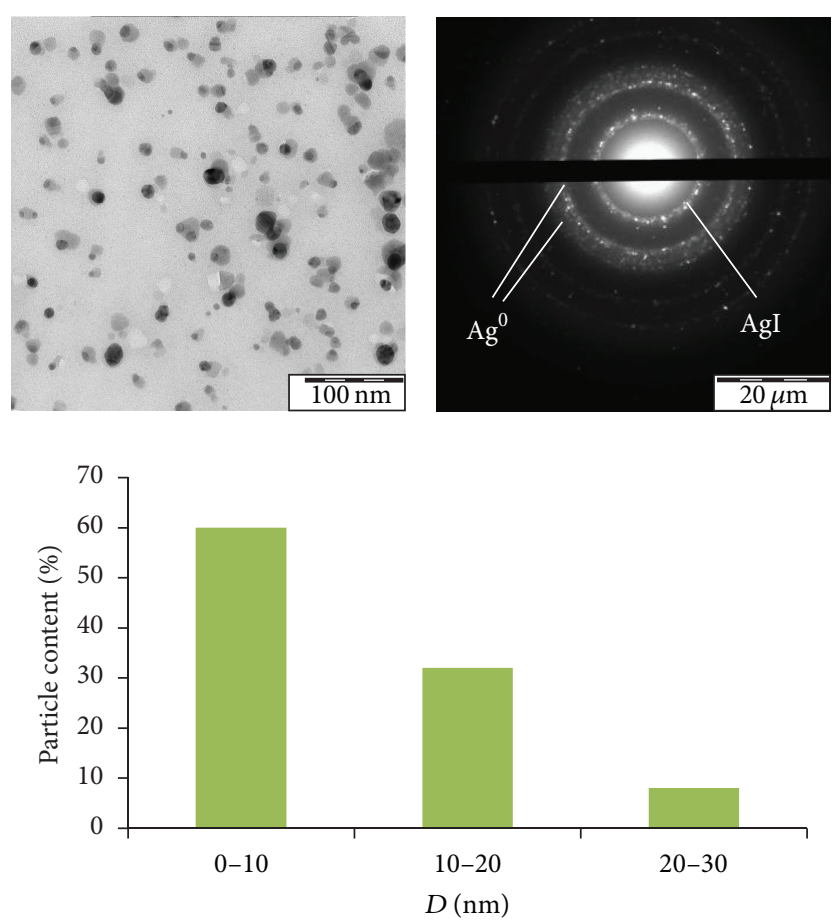

FIGURE 6: Electron micrographs, electron microdiffraction data, and histograms of the size distribution of silver iodide nanoparticles stabilized with Tween 80 .

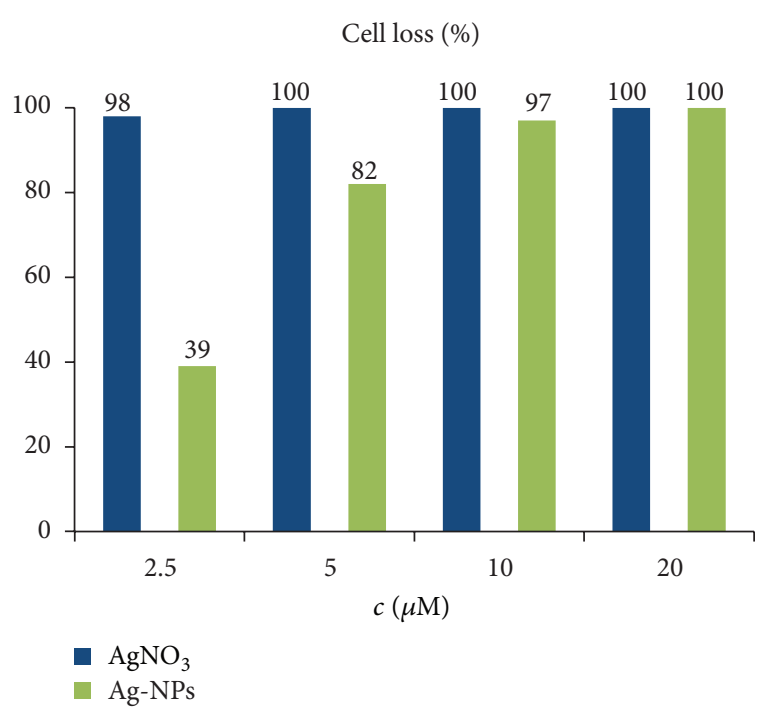

Figure 7: Survival rate of yeast cells incubated with $\mathrm{AgNO}_{3}$ solutions and silver NPs colloids.

finding and the obtained data concerning the rate of $\mathrm{K}^{+}$ efflux induced by silver NPs and $\mathrm{AgNO}_{3}$ the concentration of $\mathrm{Ag}^{+}$-ions in the studied dispersion may be estimated as about $15 \%$ of the total concentration of silver. Nearly the same value was obtained from the direct measurements of the $\mathrm{Ag}^{+}$ concentration in the synthesized nanosilver dispersion by $\mathrm{Ag}^{+}$-ion selected electrode before the incubation with yeast cells.

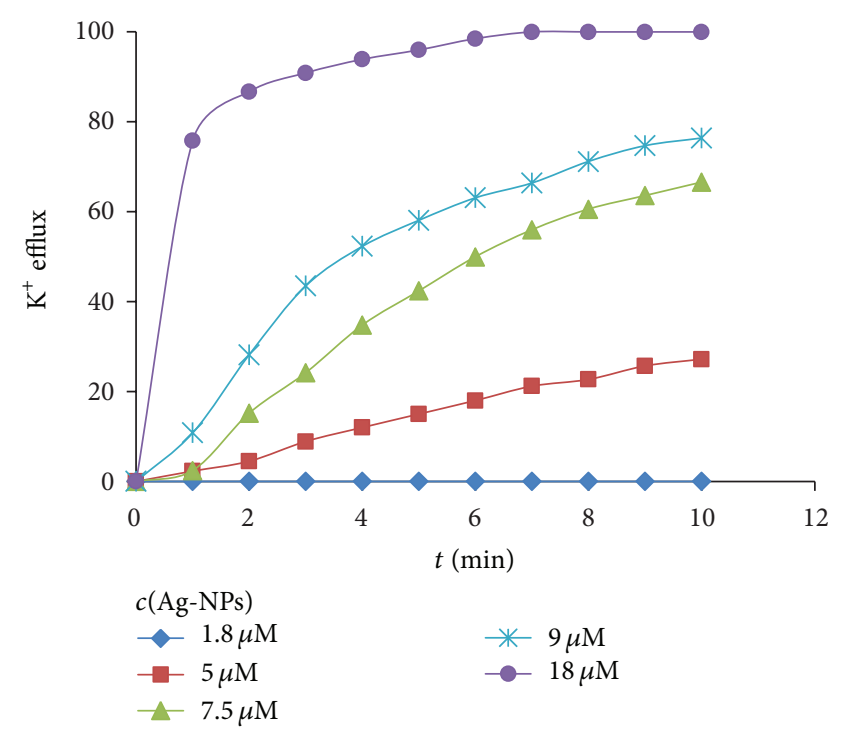

FIGURE 8: The rate of $\mathrm{K}^{+}$efflux from the yeast cells incubated with silver NPs colloids.

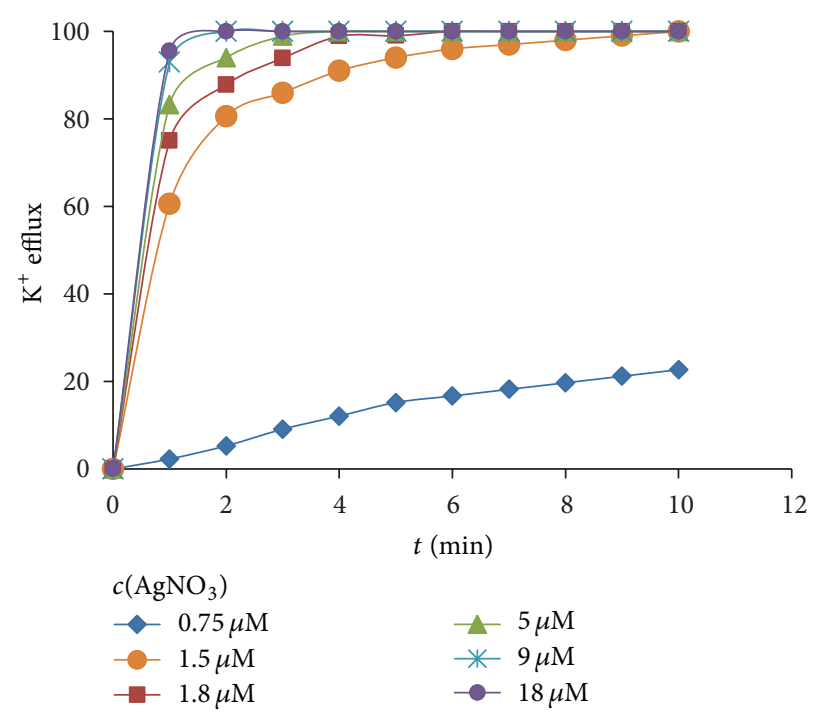

FIgURE 9: The rate of $\mathrm{K}^{+}$efflux from the yeast cells incubated with $\mathrm{AgNO}_{3}$ solutions.

Short time after the reduction of $\mathrm{AgNO}_{3}$ with the excess of strong reducing agents like sodium borohydride silver ions in dispersion of as obtained silver nanoparticles are of course absent. But then metallic silver nanoparticles inevitably generate $\mathrm{Ag}^{+}$ions during the contact of resulting dispersion with oxygen or by the action of reactive oxygen species generated in living cells. To estimate the rate of oxidation of silver nanoparticles we used the sensitive spectrophotometric technique using 1,10-phenanthroline and bromopyrogallol red. These organic substances formed an intensely blue ternary complex with ionic silver contained in silver NPs sol which then easily registered at the wavelength of $635 \mathrm{~nm}$. Since the absorption spectrum of silver nanoparticles has a maximum at $405-415 \mathrm{~nm}$, the presence of silver nanoparticles 


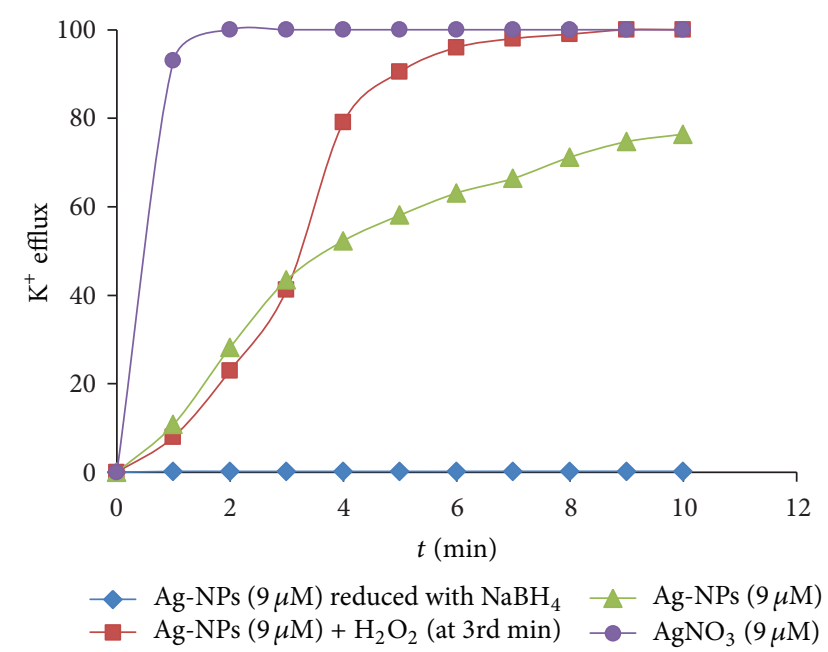

FIGURE 10: The rate of $\mathrm{K}^{+}$efflux from the yeast cells incubated with silver NPs colloids treated with $\mathrm{NaBH}_{4}$ and $\mathrm{H}_{2} \mathrm{O}_{2}$ and the corresponding curve for the yeast cells incubated with $\mathrm{AgNO}_{3}$ is shown for comparison.

did not interfere with the spectrophotometric determination of ion $\mathrm{Ag}^{+}$at $635 \mathrm{~nm}$. Intense bubbling of air for 30 minutes through silver nanoparticles dispersion does not result in appearance of the absorption bands in the spectrum of the ternary complex, while adding sufficient amounts of hydrogen peroxide leads to a rapid (within 3 minutes) quantitative oxidation of nanoparticles with formation of silver ions, which leads to a significant increase in activity against living cells.

3.1.2. Microbiological Activity of Silver Halides Dispersion. Taking into account that the biocidal activity of silver NPs against the Saccharomyces cerevisiae cells is mainly a result of the silver ions action it could be assumed that slightlysoluble silver salts which can generate silver ions when slowly dissolving may provide prolonged biocidal action as strong as the action of silver nanoparticles. The usage of nanodispersed silver salts as biocidal agents has a big potential as a way to provide a sufficiently intense and at the same time permanent and long-term release of silver ions. To further understand the mode of action of poorly soluble silver salts dispersion on living cells, we also studied the effect of silver halides on the $\mathrm{K}^{+}$efflux rate from Saccharomyces cerevisiae cells. Figure 11 shows the dependence of the release of $\mathrm{K}^{+}$from the cells by incubation time with dispersion of silver halide.

Comparing the data from Figure 8 it can be seen that the efficiency of biocidal effect of silver halide substantially exceeds the cytotoxic activity of silver nanoparticles and is comparable to that of silver nitrate solution of the same concentration. However, at the initial stage of incubation the rate of release of potassium ions from the cells under the influence of nanoparticles of silver halides is several times less than the rate of release of potassium ions due to the action of silver nitrate. This delay is apparently due to the slow dissolution of silver halides in citrate buffer. The solubility of

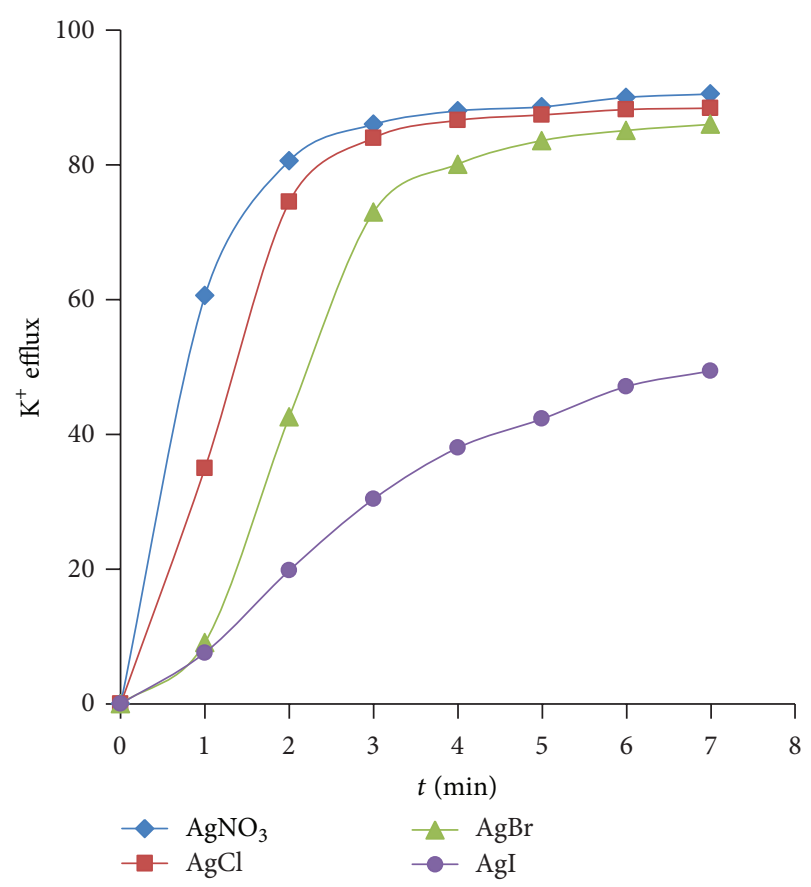

FIGURE 11: The rate of $\mathrm{K}^{+}$efflux from the yeast cells incubated with silver halides colloids with silver concentration of $1.5 \mu \mathrm{M}$.

silver halides in $0.01 \mathrm{M}$ citrate buffer ( $\mathrm{pH} 6.0$ ), which can be calculated taking into account the possibility of the formation of complexes in solution $[\mathrm{AgHal}]^{0},\left[\mathrm{AgHal}_{2}\right]^{-}$и $[\mathrm{AgCit}]^{2-}$ (Cit-citrate ion), equals $2.5 \mathrm{mM}$ for $\mathrm{AgCl}, 133 \mu \mathrm{M}$ for $\mathrm{AgBr}$, and $1.7 \mu \mathrm{M}$ for AgI. Thus, the NPs dispersion with a silver halide concentration of $1.5 \mu \mathrm{M}$ should be dissolved in a buffer solution. The rate of silver halides dissolution, as shown in [17], correlates with the silver salt solubility in the solution of complexing agent. This fact is in a good agreement with the observed decrease in the efflux rate of potassium ions from Saccharomyces cerevisiae cells in a row of $\mathrm{AgCl}-\mathrm{AgBr}-\mathrm{AgI}$.

\section{Conclusions}

The discussion about the mechanism of the cytotoxic activity of the dispersion of silver nanoparticles lasts for a long time and reliable data concerning the nature of main active agent are hard to obtain. The results of the present work clearly indicate that the silver ions which either remained in the dispersion of silver nanoparticles after their synthesis or were generated afterwards by oxidizing silver particles make the crucial contribution to the cytotoxic activity of citratestabilized silver NPs against yeast cells. It was also shown that this activity most likely does not relate to damage of cell membrane. The same way the cytotoxic effect of silver halide NPs can be explained with the generation of $\mathrm{Ag}^{+}$ions through NPs dissolution.

\section{Conflict of Interests}

The authors declare that there is no conflict of interests regarding the publication of the paper. 


\section{Acknowledgment}

The work at HUST was supported by the National Foundation for Science and Technology Development (NAFOSTED) through a fundamental project with code 106.99-2010.54.

\section{References}

[1] H. J. Klasen, "A historical review of the use of silver in the treatment of burns-II. Renewed interest for silver," Burns, vol. 26, no. 2, pp. 131-138, 2000.

[2] M. Ahamed, M. Karns, M. Goodson et al., "DNA damage response to different surface chemistry of silver nanoparticles in mammalian cells," Toxicology and Applied Pharmacology, vol. 233, no. 3, pp. 404-410, 2008.

[3] M. Mishra, H. Kumar, and K. Tripathi, "Diabetic delayed wound healing and the role of silver nanoparticles," Digest Journal of Nanomaterials and Biostructures, vol. 3, no. 2, pp. 49-54, 2008.

[4] B. S. Atiyeh, M. Costagliola, S. N. Hayek, and S. A. Dibo, "Effect of silver on burn wound infection control and healing: review of the literature," Burns, vol. 33, no. 2, pp. 139-148, 2007.

[5] W. Boucher, J. M. Stern, V. Kotsinyan et al., "Intravesical nanocrystalline silver decreases experimental bladder inflammation," Journal of Urology, vol. 179, no. 4, pp. 1598-1602, 2008.

[6] P. L. Drake and K. J. Hazelwood, "Exposure-related health effects of silver and silver compounds: a review," Annals of Occupational Hygiene, vol. 49, no. 7, pp. 575-585, 2005.

[7] A. B. Lansdown and A. Williams, "How safe is silver in wound care?" Journal of Wound Care, vol. 13, no. 4, pp. 131-136, 2004.

[8] A. B. G. Lansdown, "Silver in health care: antimicrobial effects and safety in use," Current Problems in Dermatology, vol. 33, pp. 17-34, 2006.

[9] A. L. S. Chang, V. Khosravi, and B. Egbert, "A case of argyria after colloidal silver ingestion," Journal of Cutaneous Pathology, vol. 33, no. 12, pp. 809-811, 2006.

[10] A. Dror-Ehre, H. Mamane, T. Belenkova, G. Markovich, and A. Adin, "Silver nanoparticle-E. coli colloidal interaction in water and effect on E. coli survival," Journal of Colloid and Interface Science, vol. 339, no. 2, pp. 521-526, 2009.

[11] S. Agnihotri and S. Mukherji, "Immobilized silver nanoparticles enhance contact killing and show highest efficacy: elucidation of the mechanism of bactericidal action of silver," Nanoscale, vol. 5, pp. 7328-7340, 2013.

[12] V. M. Vagabov, L. V. Trilisenko, and I. S. Kulaev, "Dependence of inorganic polyphosphate chain lengthon the orthophosphate content in the culture medium of the yeast Saccharomyces cerevisae," Biochemistry, vol. 65, no. 3, pp. 349-354, 2000.

[13] V. M. Vagabov, A. Y. Ivanov, T. V. Kulakovskaya, E. V. Kulakovskaya, V. V. Petrov, and I. S. Kulaev, "Efflux of potassium ions from cells and spheroplasts of Saccharomyces cerevisiae yeast treated with silver and copper ions," Biochemistry, vol. 73, no. 11, pp. 1224-1227, 2008.

[14] A. Henglein and M. Giersig, "Formation of colloidal silver nanoparticles: capping action of citrate," Journal of Physical Chemistry B, vol. 103, no. 44, pp. 9533-9539, 1999.

[15] J. Morones, "The bactericidal effect of silver nanoparticles," Nanotechnology, vol. 16, article 2346, 2005.

[16] J. L. Elechiguerra, J. L. Burt, J. R. Morones et al., "Interaction of silver nanoparticles with HIV-1," Journal of Nanobiotechnology, vol. 3, article 6, 2005.
[17] D. D. F. Shiao, L. J. Fortmiller, and A. H. Herz, "Dissolution rates of aqueous silver halide dispersions," Journal of Physical Chemistry, vol. 79, no. 8, pp. 816-821, 1975. 

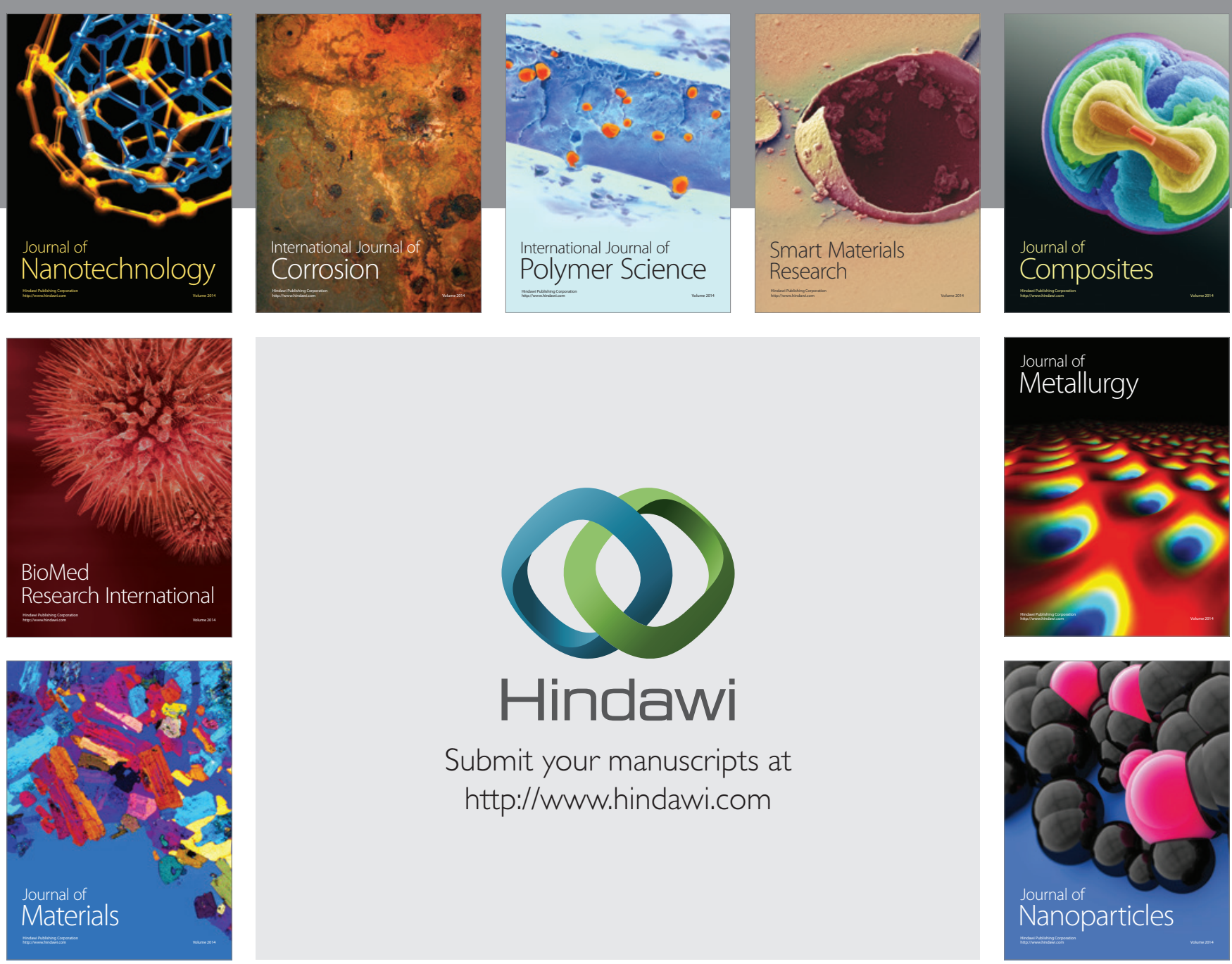

Submit your manuscripts at http://www.hindawi.com
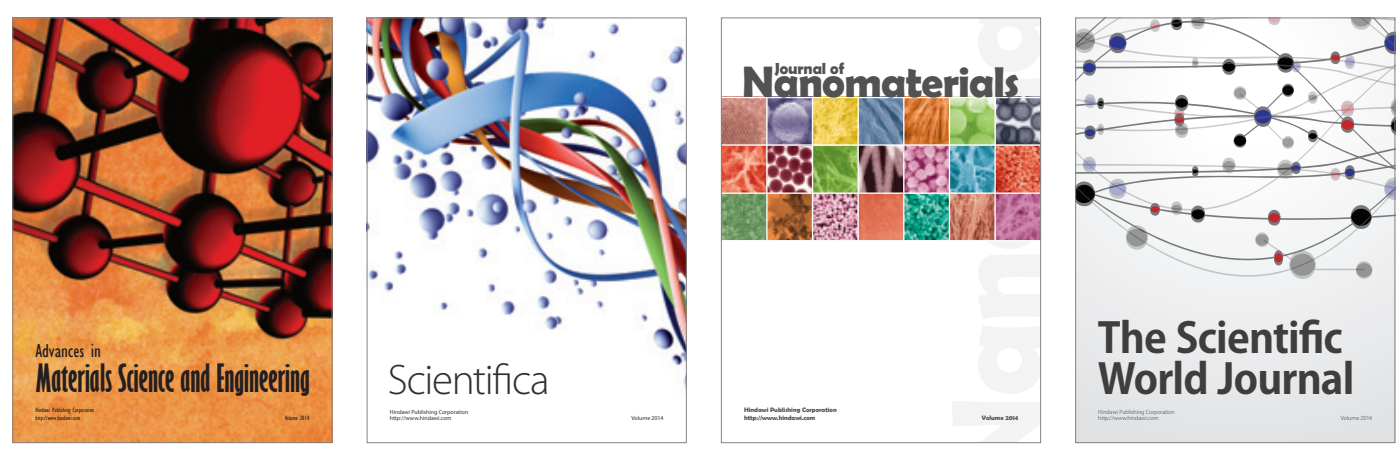

\section{The Scientific World Journal}
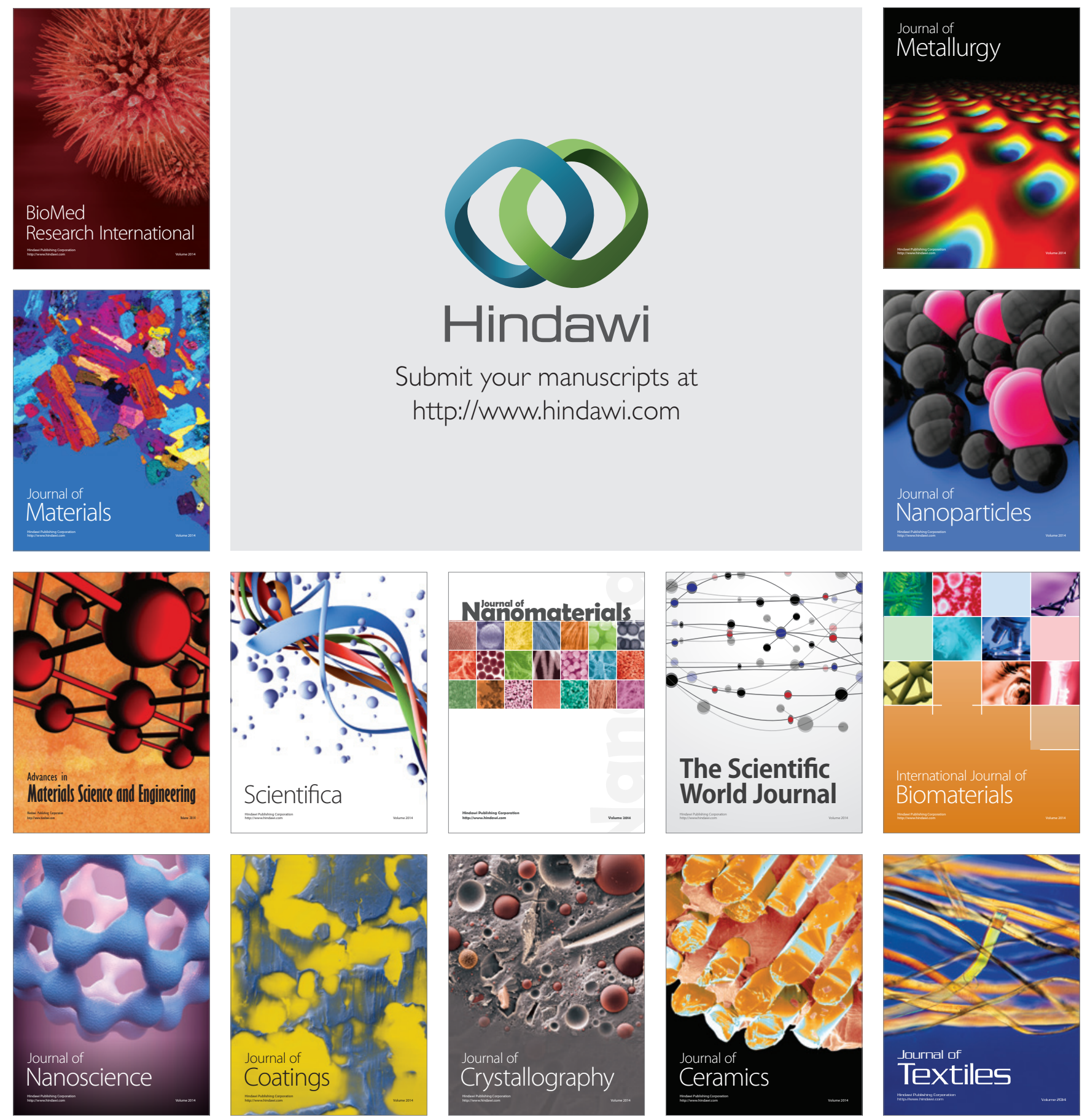